\title{
Reserve evaluation of a fault-conditioned aquifer: the Barreiras Aquifer in the coastal region of NE Brazil
}

\author{
Lucas Miguel Gomes Nunes' (D), Leandson Roberto Fernandes de Lucena ${ }^{1 *}$ (D), \\ Carlos César Nascimento da Silva' ${ }^{1}$ D
}

\begin{abstract}
Saturated thickness is a vital parameter in the assessment of hydrogeological reserves. By considering thickness variations associated with faults, the present study aimed to evaluate the water reserves of an unconfined aquifer. The study area was the Barreiras Aquifer in the lower course of the Maxaranguape River in Brazil. The methodology involved morphotectonic and lithostratigraphic analysis, well profile correlation, and hydrogeological and geoelectrical analysis (vertical electrical sounding, VES). The morphotectonic analysis employed topographical (Shuttle Radar Topography Mission) and hydrographical data to support the structural characterization, considering the lack of outcrops with specific features in the area. The results of these assessments enabled the creation of a morphotectonic lineament map, highlighting the prevailing NE and NW directions. The hydrogeophysical cross sections obtained from geoelectrical inverse models and well data reveal saturated thickness values ranging from 19 to $66 \mathrm{~m}$, featuring some lineaments as faults. The hydrogeological reserve was calculated based on 18 subareas associated with blocks resulting from structural compartmentalization. Based on an area of approximately $250 \mathrm{~km}^{2}$, the average saturated thickness for each subarea, and an average effective porosity of $7.6 \%$, the saturated reserve is estimated to be $8.7 \times 10^{8} \mathrm{~m}^{3}$.
\end{abstract}

KEYWORDS: Hydrogeological reserves; faults; morphotectonic analysis; geoelectrical models; Barreiras Aquifer.

\section{INTRODUCTION AND OBJECTIVES}

The Barreiras Aquifer, present mostly on the east coast of Rio Grande do Norte (RN), Brazil, is the largest groundwater source on the state's eastern coast and the main water source for municipalities in the region (Lucena 2018). The study area, covered by the Maxaranguape River's lower course, is included in the Barreiras Aquifer hydrogeological domain and has an approximate area of $250 \mathrm{~km}^{2}$ (Fig. 1). This region is a strategic water reserve supplying approximately $1,300,000$ inhabitants.

Recent studies highlight the significant influence of regional structure on the hydrogeological and petrophysical properties of aquifer systems in Brazil (Lucena et al.2006, Soares et al.2007, Balsamo et al. 2010, Rodrigues et al. 2011, Lucena et al. 2013). According to Burazer et al. (2010) and Diaz et al. (2014), lithostratigraphy and geological structure are important factors that affect aquifer geometry and determine hydrogeological characteristics. Therefore, parameters such as porosity, permeability, and the effect of faults (acting either as a barrier slowing water flow or as connectors between aquifers) on hydraulic transmissivity have been examined (Pilli et al. 2012). Local structural compartmentalization of an aquifer is commonly associated

${ }^{1}$ Universidade Federal do Rio Grande do Norte - Natal (RN), Brazil E-mails: lucassns100@gmail.com, leandson@geofisica.ufrn.br, carloscesar@geofisica.ufrn.br

${ }^{*}$ Corresponding author

(C) 2020 The authors. This is an open access article distributed under the terms of the Creative Commons license. with uplift or subsidence of the hydrogeological basement by faults that often increase or decrease the saturated thickness, directly affecting the volume of the hydrogeological reserves (Lucena et al. 2013).

Therefore, the thickness of a saturated zone is an important parameter for the assessment of these reserves. These data are customarily obtained from well profiles of an area. However, wells are sometimes poorly distributed over the area of interest, resulting in a lack of information and compromising a more realistic assessment of hydrogeological reserves. To fill these information gaps, geophysical methods, notably resistivity, are commonly employed to quickly determine aquifer thickness at low cost (Lucena et al. 2013).

The evaluation of hydrogeological reserves is based on the concepts and considerations reported by Custodio and Llamas (1983) and Feitosa et al. (2008), where the volume of water stored in an unconfined aquifer is estimated primarily from aquifer area, effective porosity, and saturated thickness.

This study aimed to evaluate the hydrogeological reserves of the Barreiras Aquifer, considering the variable saturated thickness from local structural compartmentalization in the lower course of the Maxaranguape River area.

\section{GEOLOGICAL AND HYDROGEOLOGICAL SETTINGS}

The geological and hydrogeological settings of the area were obtained from a review of literature related to the region and from well data. The regional lithostratigraphy is characterized 
by a subsurface and an outcropping sequence (Bezerra 1998, Lucena et al. 2006). The subsurface sequence comprises a crystalline basement (granites, gneisses, migmatites, and granodiorites) and Mesozoic sedimentary rock deposited in the Potiguar Basin (Angelim et al. 2006). The sedimentary rocks encompass a sandstone unit correlated with the Açu Formation at the base and an interlayered carbonate and sandstone unit associated with the Jandaíra Formation at the top. The outcropping sequence consists of clastic sedimentary rocks and unconsolidated sediments of the Cenozoic age, represented by the Barreiras Formation and Quaternary cover (beach rocks, dune fields, sandy covers, beach sandstones, and alluvial and mangrove deposits). Lithologically, the Barreiras Formation contains clastic rocks, including claystones and conglomerates, with a predominance of clayey sandstones (Lucena et al. 2006, Balsamo et al. 2010).

The regional tectono-structural history reveals that the Barreiras Formation is affected by brittle Neotectonics throughout the Brazilian coast (Nogueira et al. 2006, Rossetti et al. 2011). For example, Bezerra (1998) and Lucena et al. (2006) showed that the tectonic and structural frameworks of the eastern coastal strip of RN are dominated by NE-SW and NW-SE trending structures, as defined from morphotectonic alignments and the characterization of faults. According to Nogueira et al. (2006), the formation is currently controlled by a stress field involving a maximum $\mathrm{E}-\mathrm{W}$ compressive stress $(\sigma 1)$ and a $\mathrm{N}-\mathrm{S}$ extensional stress $(\sigma 3)$ resulting from the push of the mid-ocean chain. These stresses generated dextral (NE) and sinistral (NW) strike-slip faults associated with a normal component and directly linked to the uplift and subsidence of structural blocks (Bezerra \& Vita-Finzi 2000, Bezerra et al. 2001, Bezerra et al. 2014). However, Reis et al. (2013) emphasized that the direction and magnitude of the stresses vary according to depth. In the Potiguar Basin, particularly, the authors noted a lower horizontal stress gradient mainly associated with a system of normal faults at shallow depths (500 to 2,000 m), whereas it is prominent and associated with strike-slip kinematics at greater depths (2,500 to 4,000 m).

These NE and NW fault systems possibly control the formation of the main drainage networks, with uplift and subsidence of the hydrogeological basement likely responsible for aquifer thickness variations (Lucena et al. 2006). Figure 2 is a geological map showing NW- and NE-oriented faults proposed by Angelim et al. (2006), with the lower course of the Maxaranguape River area highlighted.

The Barreiras Aquifer ( $\mathrm{RN}$ State borders) is underlain by the hydrogeological basement, represented by the top of the buried Mesozoic carbonate sequence. The sequence contains sandy clay to clayey sedimentary rocks with calciferous cementation and reduced hydraulic conductivities (Lucena et al. 2006, Silva et al. 2014). Like the formation, the Barreiras Aquifer is dominated by clayey sandstones, with a predominantly

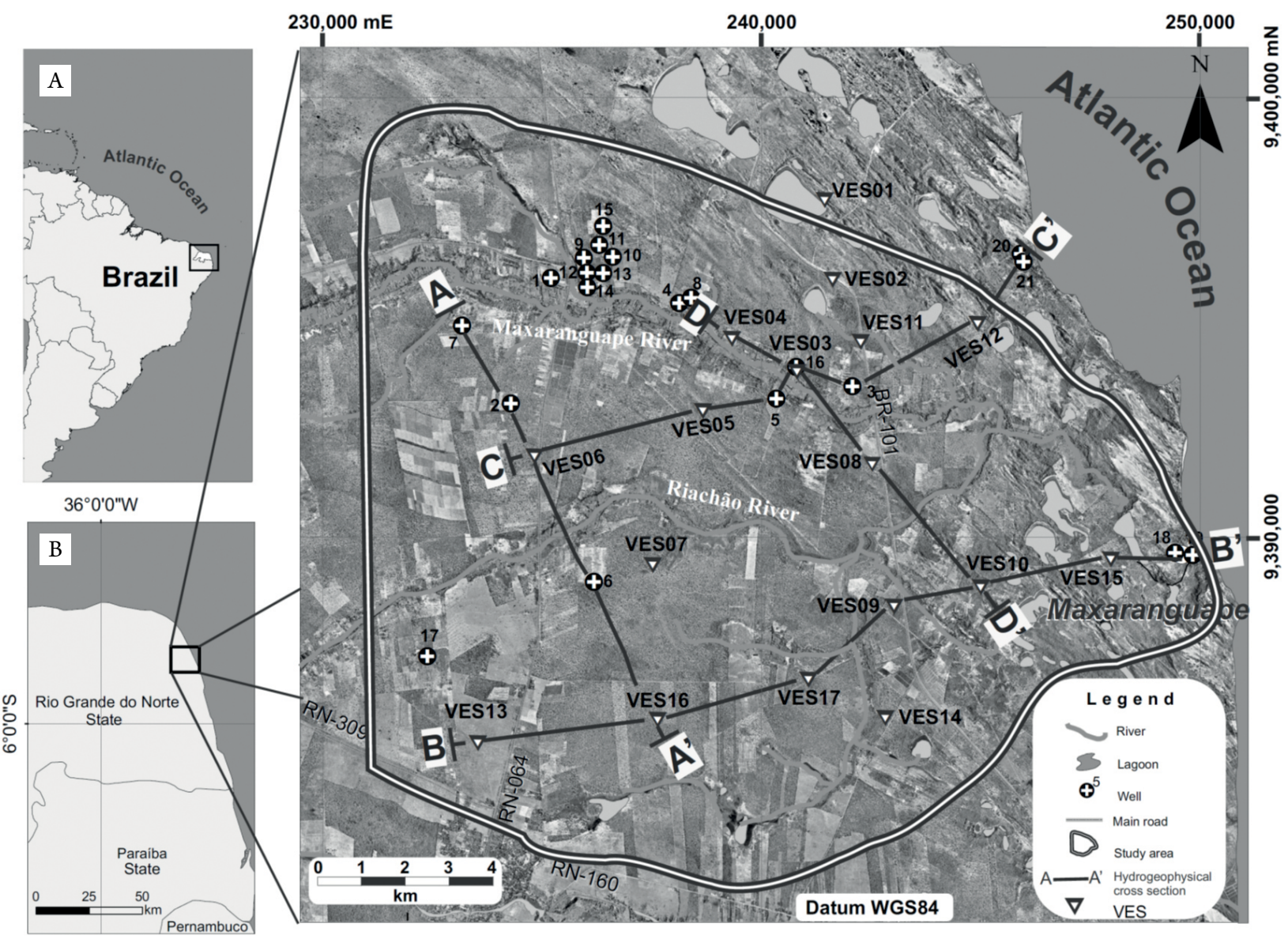

Figure 1. (A) Map showing the state of Rio Grande do Norte, Brazil; (B) the study area on the east coast of Rio Grande do Norte; (C) map of the study area showing well locations, vertical electrical soundings (VES), and hydrogeophysical cross sections (A-A, B-B', C-C, 'and D-D'). The universal transverse mercator coordinate system in (C) is used to facilitate location. 
unconfined hydraulic character (Lucena et al. 2006, Silva et al. 2014). The quaternary stratigraphic units outcropping in the region and associated with abundant sand cover and dune fields are important areas for recharge by direct infiltration of rainwater owing to high porosity, high hydraulic conductivity, and low runoff. The aquifer exploitation flow rates are proportional to the saturated thickness, reaching values of $150 \mathrm{~m}^{3} / \mathrm{h}$ in areas of high thickness, especially when associated with sandier lithologies (Lucena et al. 2006). Melo et al. (2013) performed pumping tests in the area to evaluate parameters such as hydraulic conductivity and transmissivity, reporting average values of $1.0 \times 10^{-4}$ and $3.0 \times 10^{-3} \mathrm{~m}^{2} / \mathrm{s}$, respectively, for the unconfined aquifer. Silva et al. (2014) obtained an average effective porosity of $7.6 \%$ from petrophysical studies and image processing of thin sections of the Barreiras Formation. These samples were collected throughout the east coast of the state of RN. This methodology is similar to that applied to petroleum systems and was considered to be relatively accurate in this assessment. This methodology involves a series of steps designed to obtain the hydrogeological parameters; these steps include field sampling, thin rock section lamination, image acquisition, segmentation or binarization of the two-dimensional images, and image processing (Lucena et al. 2016). Effective porosity is obtained by measuring the interconnected porous medium space in a representative elementary volume of the image. The adopted value is even more conservative when compared with other works performed in the same hydrogeological context (Lucena 2005, Righetto \& Dias 2016). Figure 2B shows a constructed lithological profile representative of a well in the area, highlighting lithological variations, the saturated and unsaturated thicknesses, and the top of the hydrogeological basement characterized by sandstone with calciferous cement.

\section{METHODOLOGY}

The procedures adopted in this study are based on the methodology proposed by Lucena (2018) but using alternative filters (matrix analysis) in the treatment of the geomorphological data employed in the characterization of the regional structure. Thus, the methodology in this research involves a review of the literature, characterization of datasets, geological (morphotectonic and lithostratigraphic analysis, correlations of well data, and available geological maps) and hydrogeological investigations (hydrogeological framework), and applied geophysical (resistivity) survey.

The electrical resistivity method, known for its applicability in groundwater research (Kirsch 2009), was used to estimate aquifer thickness values and the depths of the hydrogeological basement. The survey was conducted through vertical electrical sounding (VES), to obtain data in areas with few or no wells with available constructed lithological profiles, using the Schlumberger electrode array (Orellana 1972, Kirsch 2009).

Owing to a lack of well logs providing resistivity values of the layers in situ, electrical sounding was performed for calibration, which was necessary to minimize ambiguities inherent in the interpretation of resistivity curves. The calibration was performed adjacent to a well with a known constructed lithological profile representative of the geology of the area, enabling the geoelectrical characterization of various local hydrostratigraphic horizons. Thus, we obtained a geoelectrical model (resistivity $\times$ thickness) incorporating lithostratigraphic and hydrogeological constraints to support the quantitative interpretation of other VES.

The survey involved $17 \mathrm{VES}$ with a maximum aperture of the current electrodes $(\mathrm{AB})$ of $1,200 \mathrm{~m}$ and was designed to cover the entire study area, although it was primarily intended to generate data for areas with little or no well information (Fig. 1).

The "resistivity $x$ thickness" inverse models of the performed VES were obtained via the IPI2Win software, version
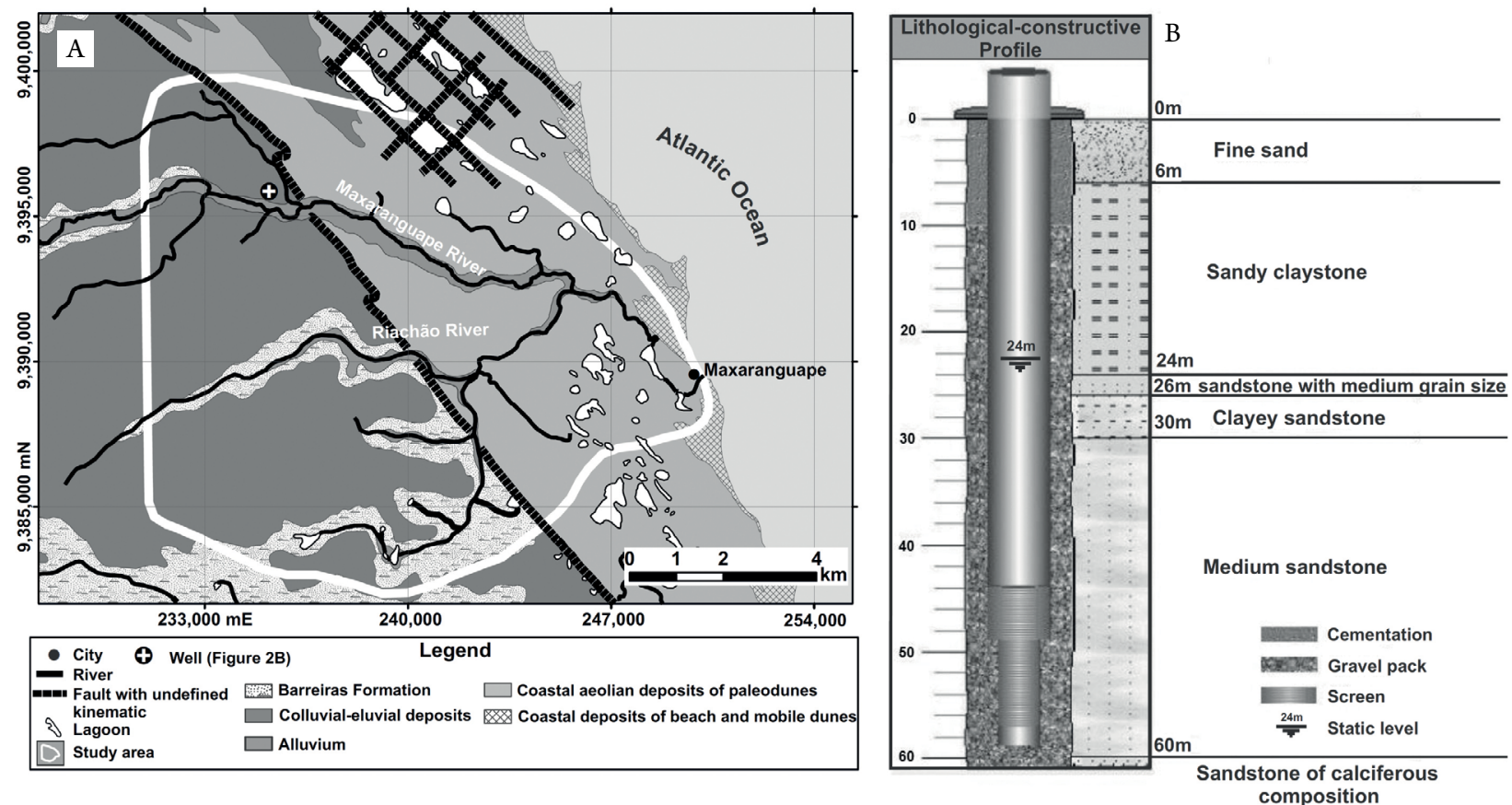

Figure 2. (A) Geological map showing the NW and NE faults (adapted from Angelim et al.2006) and the study area; (B) constructed lithological profile representative of the area, highlighting lithological variations, the unsaturated and saturated zones, and the hydrogeological basement. 
2.1 (Bobachev et al. 2000). Although consistent with the regional geology, the following geoelectrical model (Orellana 1972) was used:

- The subsoil consisted of a multilayer sequence with finite thicknesses $(\mathrm{Ti})$, except for the last, which had infinite thickness;

- Each layer was assumed to be electrically homogeneous and isotropic and characterized by resistivity $\left(\rho_{\mathrm{i}}\right)$;

- The interfaces between the layers are flat, horizontal, and parallel to the ground surface.

The well logs used comprised 21 constructed lithological profiles, preferentially those that fully crossed the Barreiras Aquifer (drilling that attained the hydrogeological basement). All well data and interpretive VES models were subjected to geostatistical treatment (interpolation and gridding) using the Surfer-Golden Software (Surfer 2010) to map aquifer thicknesses in the study area.

Geomorphological analysis was primarily conducted to support the regional structural characterization, given the lack of outcrops with kinematic criteria for such a study. Therefore, anomalies in drainage networks and land reliefs different from the patterns of surface features of a given region were associated with structures in the subsurface, reflecting the structural framework of the area (Bezerra 1998, Lucena et al. 2006). In this respect, structural trends can be characterized by features such as valley alignment and elevations in preferred directions, springs, abrupt deflections of fluvial channels, and linear water bodies (Souza et al. 2019).

Thus, a structural study with emphasis on the partitioning of the aquifer was performed through the geomorphological analysis based on topographical and hydrographical data. In identifying hidden/covered structures, morphotectonic alignments with geomorphological features and tectonic and structural connotations obtained by analyzing the topographical and drainage lineaments were defined (Pelletier 2013). Some of the alignments were defined as, or determined to be, morphotectonic faults. These resulted from the identification of downthrow in the hydrogeophysical cross-sections, measured by the variations at the top of the hydrogeological basement. In the geomorphological analysis, the boundaries of the study area were extrapolated to better characterize the patterns and regional hydrographical features.

Topographical data were extracted from a digital elevation model (Shuttle Radar Topography Mission — SRTM) of Brazil (Miranda 2015), with horizontal resolution of $75 \times 75 \mathrm{~m}$ and 259,489 data points (X, Y, Z). This dataset was subjected to geostatistical interpolation (kriging method) and gridding (Christakos 2000, Landim 2003) using the Surfer software. A topographical map with 10-m contour intervals generated in this study is referred to as the total topographical map. The total topographical map was separated into regional and residual components to identify and better relate the topographical lineaments (TL) with structural features in the subsurface. In general, this procedure involved the subtraction of regional components from the total topographical field to highlight residual anomalies of morphotectonic nature. Therefore, the separation of regional and residual components from the total topographical field was based on a filtering process. A lowpass filter was applied to the $3 \times 3,5 \times 5$, and $9 \times 9$ matrices to create maps with different smoothing levels of the regional component (Jordan et al. 2005). Once the most appropriate regional map was chosen $(9 \times 9$ matrix $)$, the regional field was subtracted from the total field, resulting in a map emphasizing features of higher frequencies; this was referred to as the residual topographical field. After defining the residual topographical map, the TL were added based on the continuity of isolines and/or boundaries between topographical highs and lows.

The hydrographical analysis involved the identification of anomalies in the drainage network and other surface water bodies, denoting concealed structural features. These anomalies are related to abrupt deviations of rivers or lakes along a direction or elongated, springs alignment along preferential directions and others. The linear drainage segments, termed drainage lineaments (DL), were obtained from the local hydrographical and total topographical maps reported in the topographical analysis.

The statistical analysis of the drainage data and respective azimuths were plotted in rosette diagrams. Based on the dimensions of the drainage network area, $100 \mathrm{~m}$ was chosen to standardize the shortest possible length for observation in an orbital scale image. The geomorphological analysis data were subsequently summarized in a map exhibiting the principal morphotectonic alignments in the area.

Characterization of some of the morphotectonic alignments such as faults resulted from the measurement of the downthrow in the hydrogeophysical cross-sections. The latter were prepared from inverse interpretive models of the VES and the well profiles to intercept morphotectonic alignments and anomalies observed in the aquifer thickness map. Thus, the defined structural blocks were bounded by faults, morphotectonic alignments, or even the geographical boundaries of the basin occupying a $250 \mathrm{~km}^{2}$ area. However, this western boundary was defined by additionally considering that the aquifer thickness values gradually decline after this limit; this was based on well data and consideration of the proximity of the contact between the East Coastal and Potiguar basins (occurrence of carbonate outcrops in the basin nearest the western boundary).

The local hydrogeological reserves of the aquifer with unconfined hydraulic character were measured using the effective porosity $\left(\eta_{\mathrm{e}}\right)$, the average local saturated thickness (B), and the respective area (A) (Custodio and Llamas 1983, Feitosa et al.2008). This evaluation was performed separately for each structural block (n) using the saturated thickness and subarea of occurrence. The total reserve is the sum of the individual reserves (Lucena 2018; Eq. 1). Based on previous research on the Barreiras Aquifer by Silva et al. (2014), a single effective porosity value was taken as representative for all subareas.

$\mathrm{V}_{\text {sTOTAL }}=\Sigma \mathrm{A}_{\mathrm{n}} \cdot \mathrm{B}_{\mathrm{n}} \cdot \eta_{\mathrm{e}}$

To define the saturated thickness for each subarea or structural block (unit) with an isopach distribution involving an approximate linear gradient along each structural block, we assumed a mean saturated thickness (ST) for each 
corresponding subarea. Thus, the maximum $\left(\mathrm{B}_{\max }\right)$ and minimum $\left(\mathrm{B}_{\min }\right)$ values of the ST were calculated while obeying the geological constraints (Eq. 2).

$\mathrm{B}_{\mathrm{n}}=\left(\mathrm{B}_{\text {max }}+\mathrm{B}_{\text {min }}\right) / 2$

In this study, we adopted a structural compartmentalization model based on a fault system with a normal interpretive character. This considered the observations of Reis et al. (2013) relating to the predominance of normal components in the shallower regional brittle systems. Thus, reserves were assessed using approximate vertical limits of the structural blocks. This simplification is supported by the fact that this aquifer system is buried at $150 \mathrm{~m}$ depth. A simplified flow chart of the proposed methodology is displayed in Figure 3.

\section{RESULTS AND DISCUSSION}

The integration of data from the geomorphological analysis, geoelectrical surveys, and well profiles improved the characterization of the structural aspect of the study area. This improvement optimized the assessment of the water reserves for the Barreiras Aquifer involving structural compartmentalization.

In the geomorphological analysis of topography, residual components of relief patterns associated with the structure of the area were obtained by subtracting the regional components from the total topographical field. In this procedure, the $9 \times 9$ matrix for geostatistical processing of the regional and residual components was the most representative of the topographical constraints of the area. The other matrix configurations $(3 \times 3$ and $5 \times 5)$ were ignored because the regional components from low-pass filtering tended to incorporate residual features (Fig. 4). Some of the residual features are exemplified in the $3 \times 3$ and $5 \times 5$ configurations by white lines in Figures 4B and 4C. In the $9 \times 9$ configuration (Fig. 4D), the residual features were partially or totally filtered in the final analysis. However, the negative values observed in the residual topographical maps were from the data subtraction process and should not be dissociated from real altimetry data.

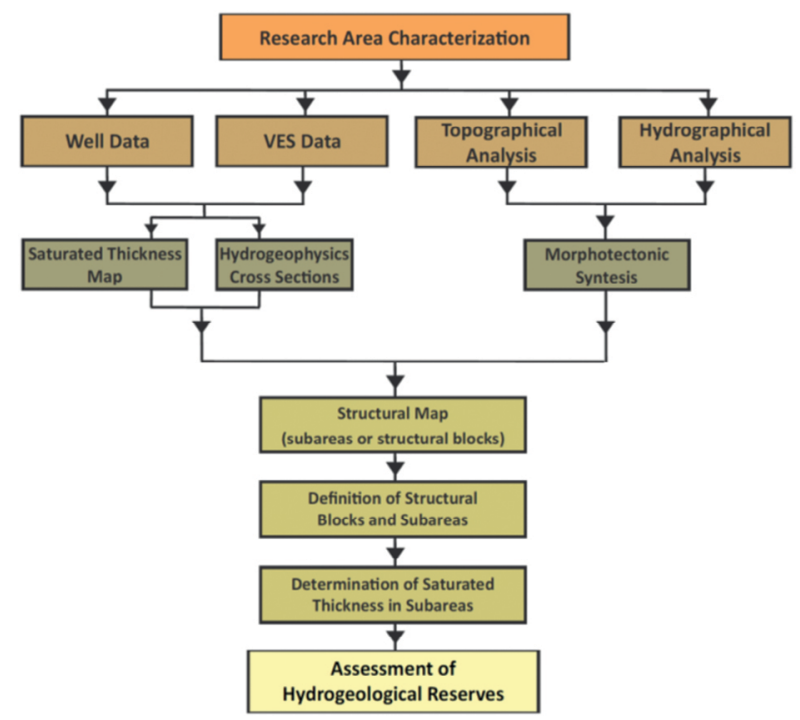

Figure 3. Simplified flow chart of the proposed methodology.
The hydrographical and geomorphological analysis defined DL in two different contexts: extrapolating the study area and limited to it. The aim of using this procedure was to obtain a more consistent characterization of possible anomalies. A total of 1,115 DLs was produced in the first case, whereas only 774 were defined inside the study area. In both cases, the NE and NW trends were conspicuous and roughly concordant with the $\mathrm{N} 50^{\circ}-60^{\circ} \mathrm{E}$ and $\mathrm{N} 40^{\circ}-60^{\circ} \mathrm{W}$ (regional analysis), and $\mathrm{N} 50^{\circ}-60^{\circ} \mathrm{E}$ and $\mathrm{N} 40^{\circ}-50^{\circ} \mathrm{W}$ (local analysis) directions.

Figure 5 shows the main TL outlined in the $9 \times 9$ matrix residual map (5A), DL (5B), and rosette diagrams related to regional and local analysis (5C and 5D, respectively). As reported, these diagrams show preferred directions on drainage segments of $100 \mathrm{~m}$ or larger.

The morphotectonic alignment map highlights possible buried structures influencing the local geomorphology. It enabled further investigations aimed at improving understanding of the structural characteristics of the area.

The geoelectrical survey was conducted to collect data in subareas with little or no hydrostratigraphic information; it involved a geoelectrical calibration sounding (Fig. 6). The sounding (VES 03) occurred adjacent to a well with a defined lithostratigraphic profile (well number 16, as shown in Fig. 1). This enabled geoelectrical characterization of the main hydrostratigraphic horizons of the Barreiras Aquifer and adjacent areas. The geoelectrical model exhibited three horizons: the hydrogeological basement of the Barreiras Aquifer, the aquifer, and the overlying unsaturated zone. The first horizon is characterized by low resistivity $(\leq 80 \Omega . \mathrm{m})$ and associated with claystone and sandstone with calciferous cementation, harrowing to higher resistivity associated with the purest carbonate sequence of the Cretaceous age $(600 \Omega . \mathrm{m})$. The saturated zone is characterized by resistivity ranging from 140 to $1,100 \Omega$.m, changing from claystone to coarse and fine sandstone. The higher resistivity, in this case, is associated with cleaner sandstones, whereas the lower resistivity is characteristic of claystones and clayey sandstones. The unsaturated zone, comprising sandy sediments with clay and moisture, yielded even higher resistivity $(\geq 1,100 \Omega . m)$.

Figure 7 shows two other VES profiles representative of the area and the corresponding geoelectrical model (VES-01 and VES-02), interpreted based on the geoelectrical calibration. All other VES performed were qualitatively similar. In general, these produced high initial resistivity values (outermost layers), with a decreasing trend toward more conductive layers and a final upward trend, resembling type $\mathrm{H}$ curves (Orellana 1972). This curve is defined by the relationship $\rho_{1}>\rho_{2}<\rho_{3}$ for a basic model with three geoelectrical layers. The VES allowed the identification of the three hydro-geoelectrical horizons described in the calibration sounding, following the same range of resistivity. The aquifer thickness values were set between 19 and $60 \mathrm{~m}$, whereas the unsaturated zone thickness ranged from 1 (VES-01, near an upwelling of groundwater) to $25 \mathrm{~m}$. The inversion process to obtain the final geoelectrical model considered the geoelectrical equivalence phenomenon (Orellana 1972). Thus, ST variations up to $5 \mathrm{~m}$ only slightly change the fittings of the inverse models relative to the 


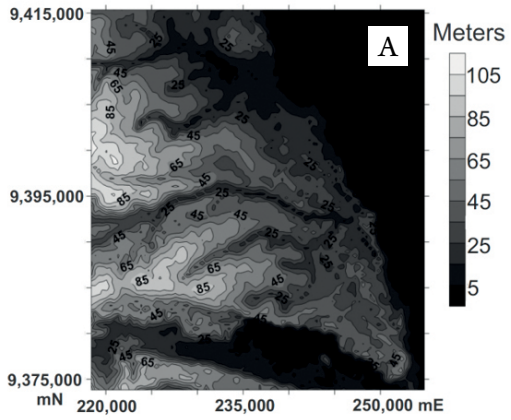

Total Topographic Map

$\mathrm{mN} 220,000$ 235,000 $250,000 \mathrm{mE}$
Regional Topographic Map

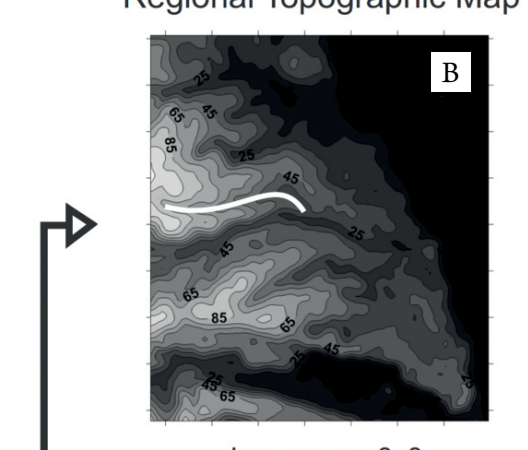

Low pass $-3 \times 3$
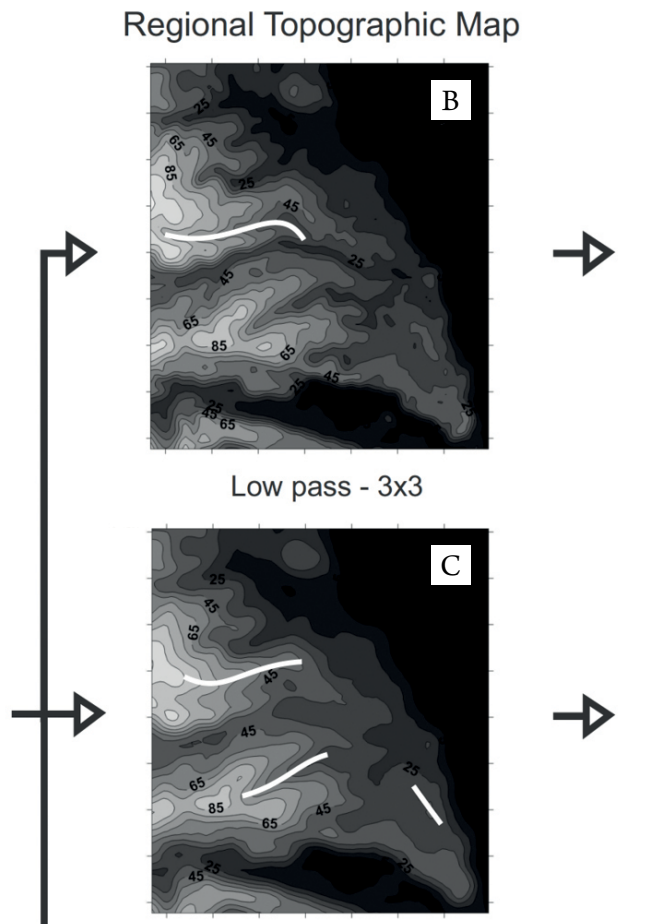

Low pass - $5 \times 5$

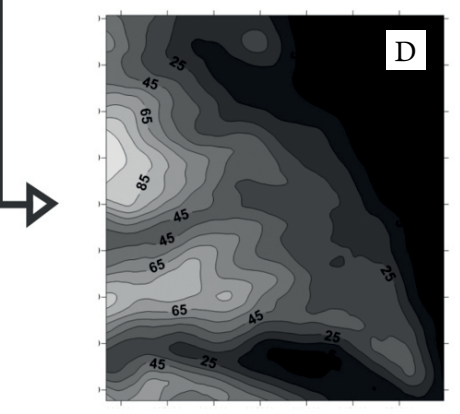

Low pass - 9x9
Residual Topographic Map

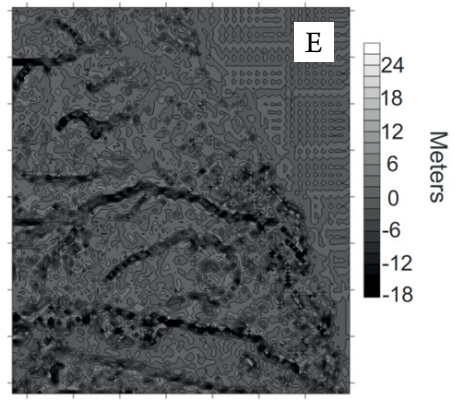

Total - Regional $(3 \times 3)$

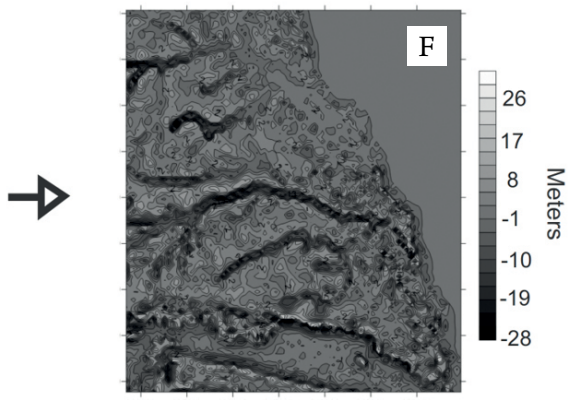

Total - Regional (5×5)

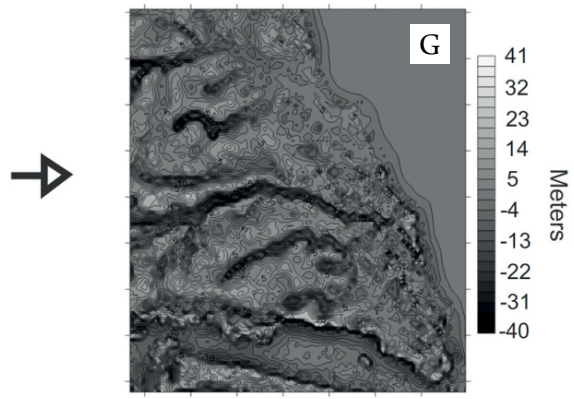

Total - Regional (9×9)

Figure 4. Summary of SRTM data processing for (A) total topographical map and regional topographical map obtained using the low-pass filter on (B) $3 \times 3$, (C) $5 \times 5$, and (D) $9 \times 9$ matrices. The residual topographical map obtained by subtracting the regional from the total topographical maps for the (E) $3 \times 3$, (F) $5 \times 5$ (F), and (G) $9 \times 9$ matrices; the white lines in (B) and (C) are examples of residual features attenuated by the processing using the (D) $9 \times 9$ matrix; all residual features were filtered in (D).
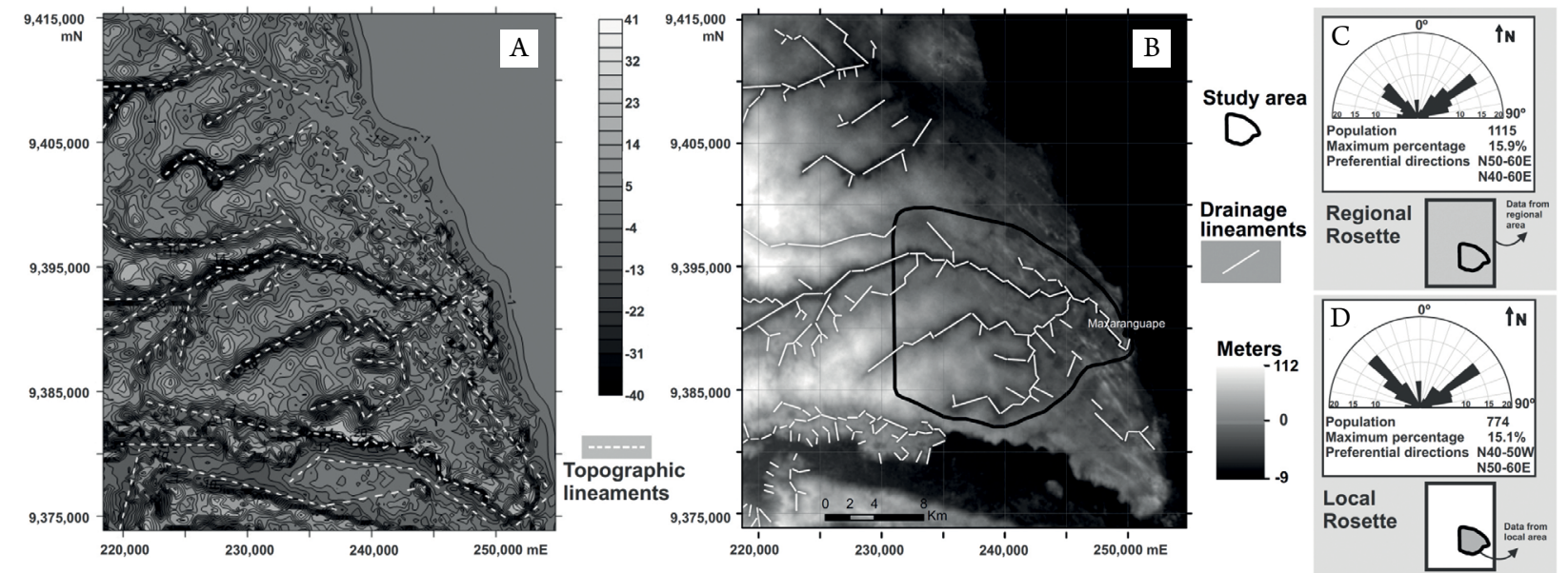

Figure 5. (A) Residual topographical map $(9 \times 9)$ with topographical lineaments; (B) map showing the SRTM and DL; (C) rosette diagram with drainage network preferred directions according to the regional analysis (extrapolating the study area); (D) rosette diagram with drainage network preferred directions (limited to the study area). 
respective geoelectrical field curves. Therefore, ST errors up to $5 \mathrm{~m}$ are incorporated in the reserve assessments.

In view of the non-uniformity of the data distribution over the area, the well and VES data were subjected to geostatistical interpolation to obtain a ST map. In this respect, the Kriging interpolation method used (Christakos 2000) has the characteristic of connecting similar magnitude values, generating well-defined contours and incorporating eventual anisotropies. Information regarding the well data used is given in Table 1.

This map (Fig. 8) shows ST values of 18 and $66 \mathrm{~m}$ in the northeast and east of the area, respectively. A central band with minor thickness variations exists at around $50 \mathrm{~m}$ in the northeast direction. Lower anomalous values were observed in the same direction in the extreme north and south of the area, where aquifer thickness values range from 35 to $40 \mathrm{~m}$. Other important aspects include substantial localized ST variations, such as the $30 \mathrm{~m}$ variation observed in the northeastern area, between VES-01 and VES02 . Such features, analyzed concomitantly with the results of the geomorphological analysis, reveal that the structure preliminarily characterized as surficial likely involves a signature in the subsurface.

The configuration of morphotectonic alignments such as faults was thus developed after the identification of downthrow
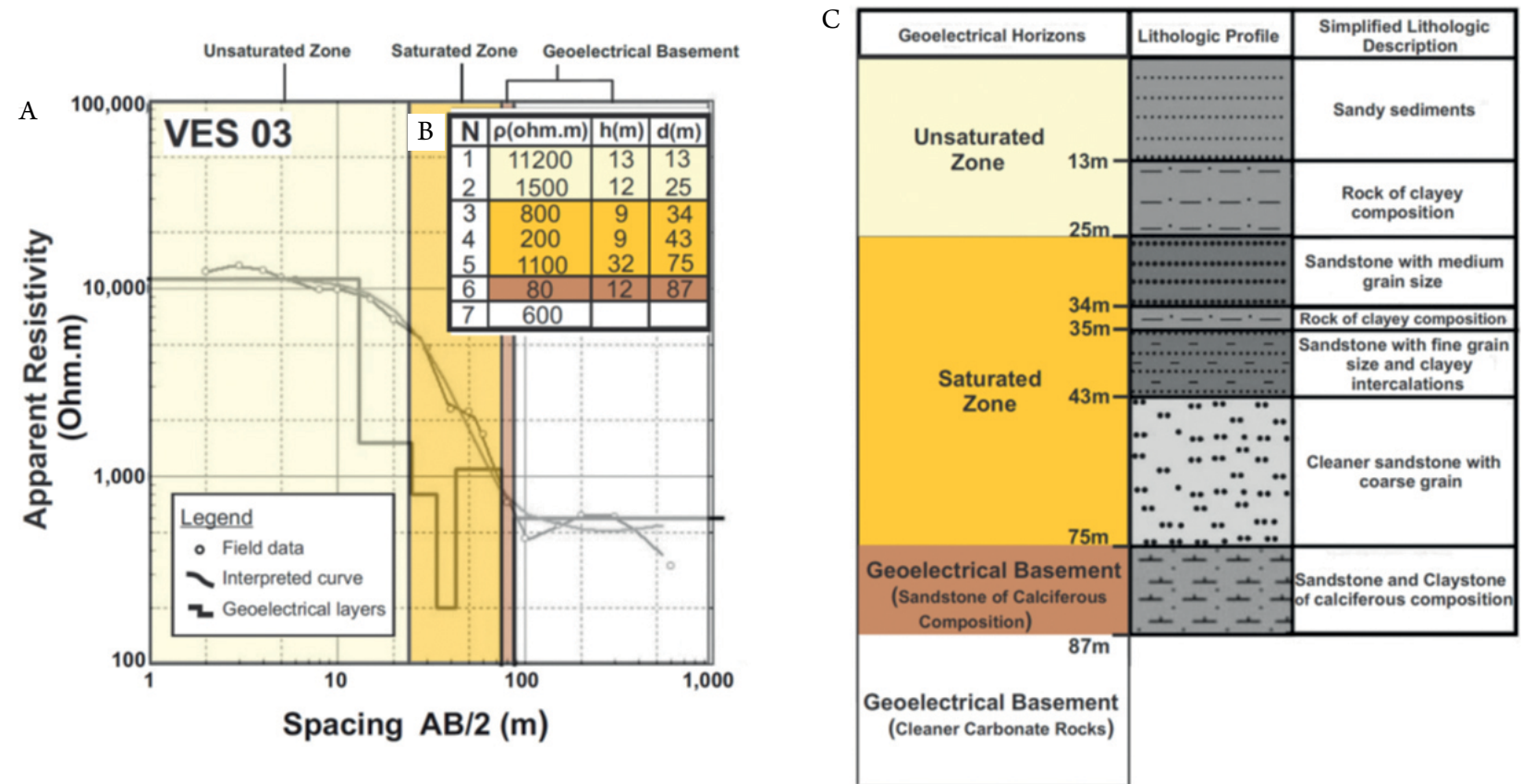

Figure 6. Geoelectrical calibration (VES-03) of (A) the apparent resistivity curve; (B) the interpreted geoelectrical model, where $\mathrm{N}$ is the geoelectrical layer, $\rho$ is the resistivity, $h$ is the thickness, and $d$ is the depth; (C) lithology of well profile and the interpreted geoelectrical horizons. See location in Figure 1.
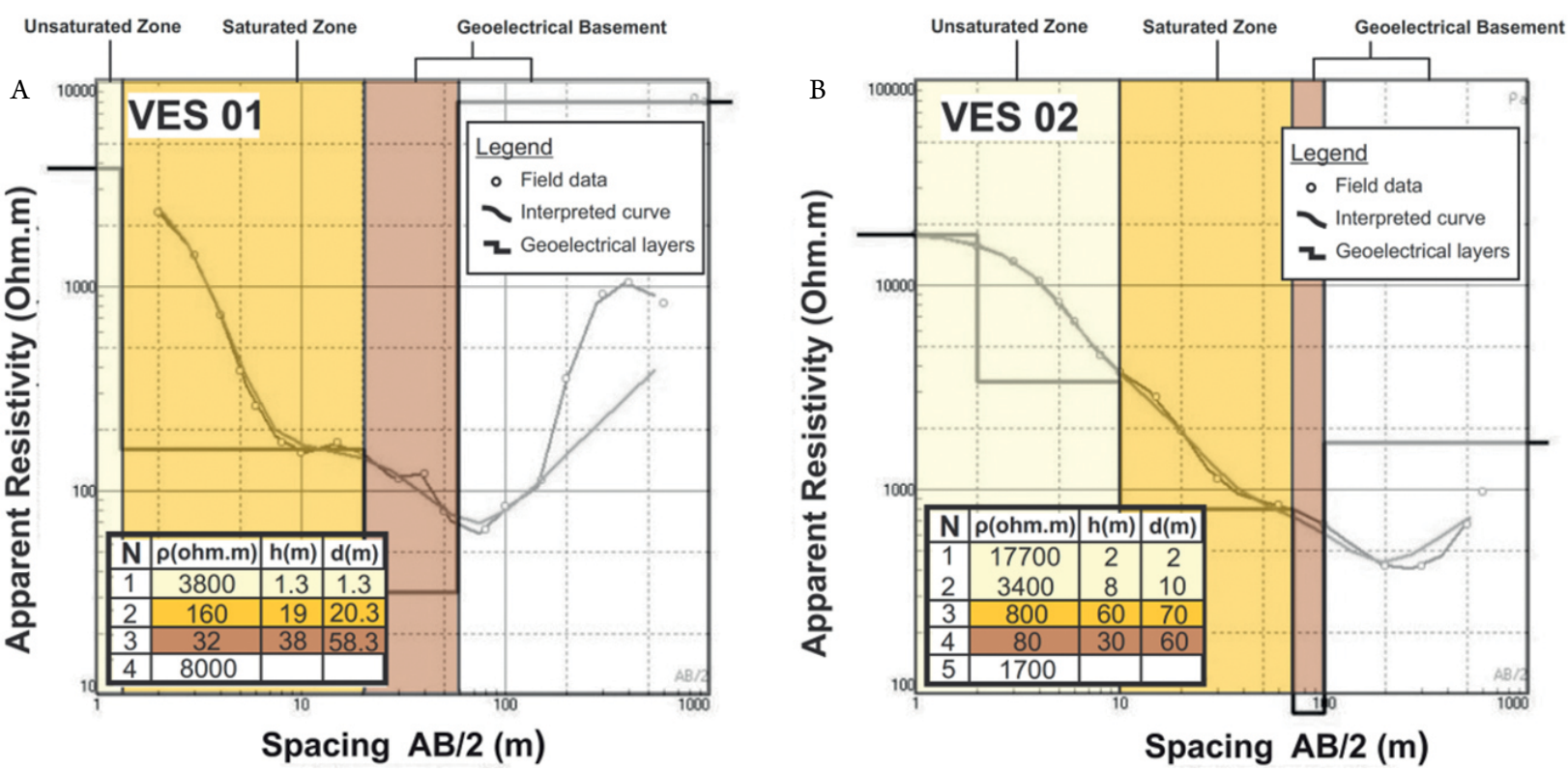

Figure 7. VES-01 (A) and VES-02 (B) apparent resistivity curves, with their respective geoelectrical models; the table shows the interpreted geoelectrical model, where $\mathrm{N}$ is the number of layers, $\rho$ is the resistivity, and $\mathrm{h}$ and $\mathrm{d}$ are the layer thickness and depth, respectively. 
Table 1. Synthesis of well data used in this study*.

\begin{tabular}{lcccccccccc}
\hline $\begin{array}{l}\text { Well } \\
\text { Index }\end{array}$ & $\begin{array}{c}\text { UTM X } \\
(\mathbf{m})\end{array}$ & $\begin{array}{c}\text { UTM Y } \\
(\mathbf{m})\end{array}$ & $\begin{array}{c}\text { Well } \\
\text { Elevation } \\
(\mathbf{m})\end{array}$ & $\begin{array}{c}\text { Well } \\
\text { Diamet. } \\
(\mathbf{i n})\end{array}$ & $\begin{array}{c}\text { Well } \\
\text { Depth } \\
(\mathbf{m})\end{array}$ & $\begin{array}{c}\text { Screen } \\
\text { Intervals }(\mathbf{m})\end{array}$ & $\begin{array}{c}\text { Static } \\
\text { Level }(\mathbf{m})\end{array}$ & $\begin{array}{c}\mathbf{Q} \\
\left(\mathbf{m}^{3} / \mathbf{h}\right)\end{array}$ & $\begin{array}{c}\text { q } \\
\left(\mathbf{m}^{3} / \mathbf{h} / \mathbf{m}\right)\end{array}$ & $\begin{array}{c}\text { Barreiras } \\
\text { Aquifer } \\
\text { Thickness }(\mathbf{m})\end{array}$ \\
\hline 1 & 235500 & 9396000 & 35 & $6 ”$ & 60 & $44-57$ & 19 & 5 & 0.5 & 41 \\
2 & 234390 & 9393040 & 48 & $6 ”$ & 62 & $38-46 / 50-59$ & 21 & 10 & 12.4 & 37 \\
3 & 242257 & 9393424 & 27 & $8 ”$ & 73 & $43-67$ & 20 & 140 & 17.1 & 47 \\
4 & 238270 & 9395352 & 31 & $8 ”$ & 55 & $33-39 / 41-53$ & 19 & 120 & 17.1 & 35 \\
5 & 240508 & 9393150 & 18 & $8 ”$ & 66 & $35-47 / 51-63$ & 13 & 113 & 11.8 & 52 \\
6 & 236300 & 9388932 & 47 & $6 ”$ & 78 & $44-56 / 68-72$ & 20 & 8 & - & 57 \\
7 & 233262 & 9394828 & 40 & $6 ”$ & 82 & $40-52 / 60-68$ & 17 & 50 & 4.9 & 55 \\
8 & 238540 & 9395465 & 32 & $6 ”$ & 60 & $38-58$ & 17 & 50 & - & 42 \\
9 & 236103 & 9396329 & 37 & $8 ”$ & 60 & $34-58$ & 19 & 60 & - & 39 \\
10 & 236742 & 9396412 & 38 & $8 ”$ & 70 & $44-68$ & 18 & 90 & - & 51 \\
11 & 236424 & 9396677 & 40 & $8 ”$ & 67 & $45-65$ & 18 & 90 & - & 48 \\
12 & 236138 & 9396041 & 37 & $8 ”$ & 57 & $35-55$ & 21 & 70 & - & 34 \\
13 & 236513 & 9396035 & 36 & $8 ”$ & 66 & $44-64$ & 20 & 78 & - & 45 \\
14 & 236152 & 9395741 & 30 & $4 ”$ & 50 & $32-48$ & 15 & 6 & - & 34 \\
15 & 236512 & 9397122 & 39 & $8 ”$ & 62 & $39-55 / 57-61$ & 12 & 90 & - & 45 \\
16 & 240964 & 9393876 & 36 & $10 ”$ & 75 & $44-60 / 64-72$ & 25 & 99 & - & 50 \\
17 & 232450 & 9387212 & 67 & $6 ”$ & 80 & $58-78$ & 35 & 22 & - & 45 \\
18 & 249700 & 9389600 & 17 & $6 ”$ & 80 & $56-78$ & 14 & 12 & 2.4 & 66 \\
19 & 250100 & 9389550 & 6 & $6 ”$ & 70 & $48-68$ & 11 & 24 & 2.5 & 60 \\
20 & 246150 & 9396480 & 8 & $6 ”$ & 49 & $37-49$ & 3 & 14 & 0.7 & 47 \\
21 & 246200 & 9396300 & 9 & $6 ”$ & 54 & $14-42 / 45-54$ & 4 & 14 & 1.7 & 50 \\
\hline
\end{tabular}

${ }^{*}$ The static levels were measured at the end of the rainless period in the region.
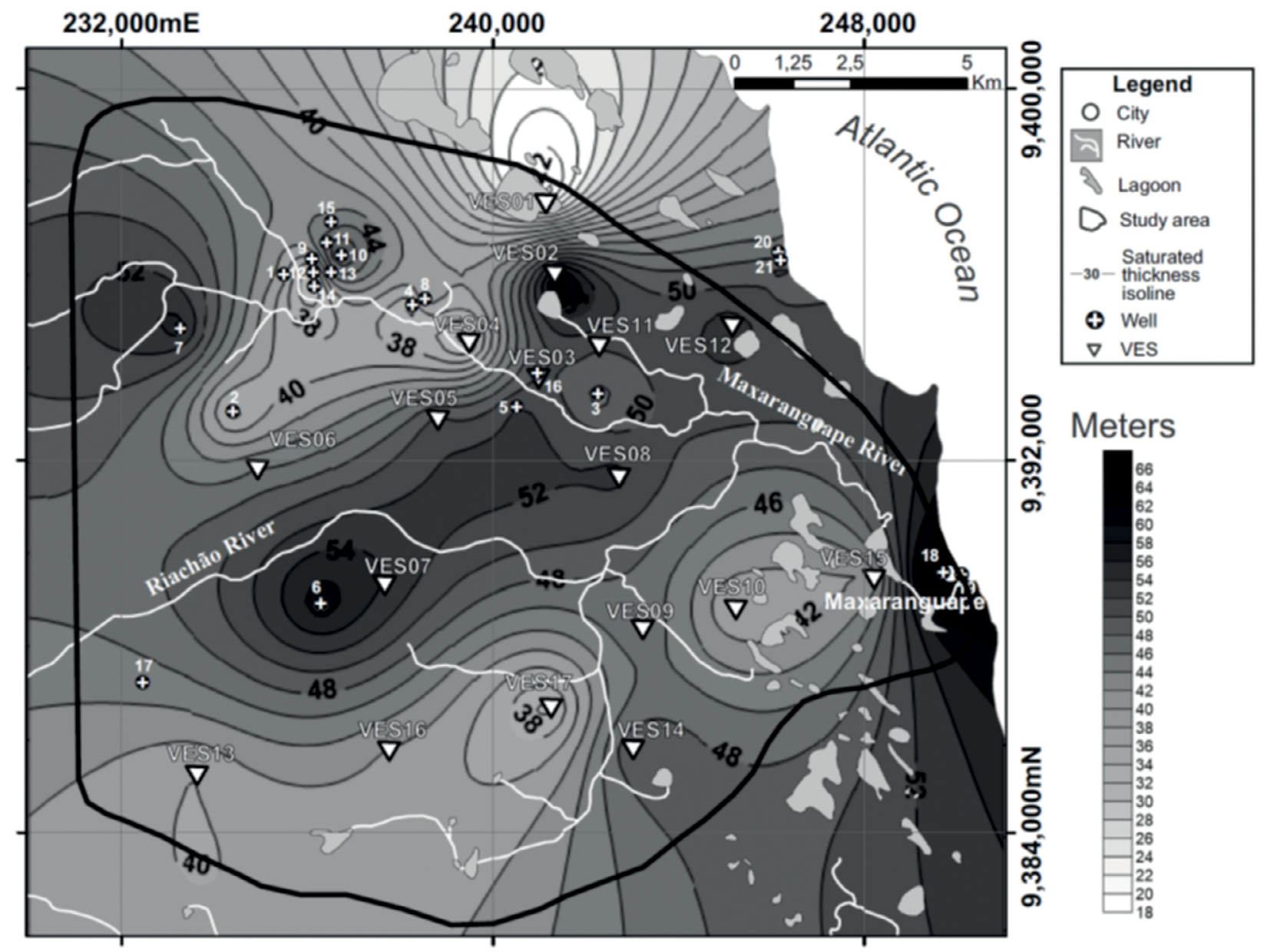

Figure 8. Saturated thickness map of the lower course of the Maxaranguape River region, derived from geoelectrical and well data. 
in the hydrogeophysical cross-sections, and this assisted in the delineation of the structural blocks. Such downthrow, measured relative to the adjacent blocks, is about $15-35 \mathrm{~m}$, with the top of the buried carbonate sequence representing the hydrogeological basement of the Barreiras Aquifer serving as a guide. Figure 9 shows the reported hydrogeophysical cross-sections (see location in Fig. 1) and the influence of the structure on the geometry of the aquifer, especially the ST variations conditioned by faults. In this figure, the faults interpreted in vertical sections are useful in generating details on previous maps in the area (e.g., Angelim et al.2006), even if the relative kinematics of the fault are uncertain.

The cross-section A-A' (NW-SE) in the area under wells 6 and 7 shows greater aquifer thickness resulting from faults with normal interpretive character, which caused subsidence of the hydrogeological basement, characterizing the local geometry as a graben. The measured downthrow faults varied between 15 and $23 \mathrm{~m}$. The cross section B-B' (SW-NE direction) also exhibited a relationship between subsidence of the hydrogeological basement and increasing thickness of the aquifer, highlighting the eastern portion of the cross section with a downthrow greater than $25 \mathrm{~m}$ and configuring a mini graben in the central region. Similarly, the cross section C-C' (NE-SW direction) displays the thickness variation of the aquifer due to normal faults, with a downthrow up to $15 \mathrm{~m}$.
The cross section D-D' (NW-SE), where continuity is highlighted in the central range of the ST map, shows NW and SE trending downthrows of 23 and $13 \mathrm{~m}$, respectively. However, basement depth variations up to $10 \mathrm{~m}$ were not interpreted as faults owing to the absence of either associated morphotectonic anomalies or geoelectrical equivalence in the reported curves.

A detailed structural map of the study area (Fig. 10) was produced from the results of geomorphological analysis involving morphotectonic alignments, the hydrogeophysical cross-sections in Figure 9, and the geological base map of Angelim et al. (2006). The main structures display NE-SW and NW-SE trends, consistent with other studies performed in the northeastern area of Brazil and reflecting the regional Neogene-Quaternary stress field (Bezerra 1998, Lucena 2005, Bezerra et al. 2014, Souza et al. 2019).

The characterization of NW and NE faults with graben and horst type structures is associated with thick and thin aquifer areas, respectively. As such, this highlights the NE graben in the central region of the map. Some morphotectonic alignments identified in the geomorphological analysis are suppressed here owing to possible causes of tectonic origin. This is plausible for some alignments in the eastern portion of the area associated with the NW-trending lagoons. These are related primarily to interdune valleys associated with the preferred southeast direction of the winds in the area. Thus, only the
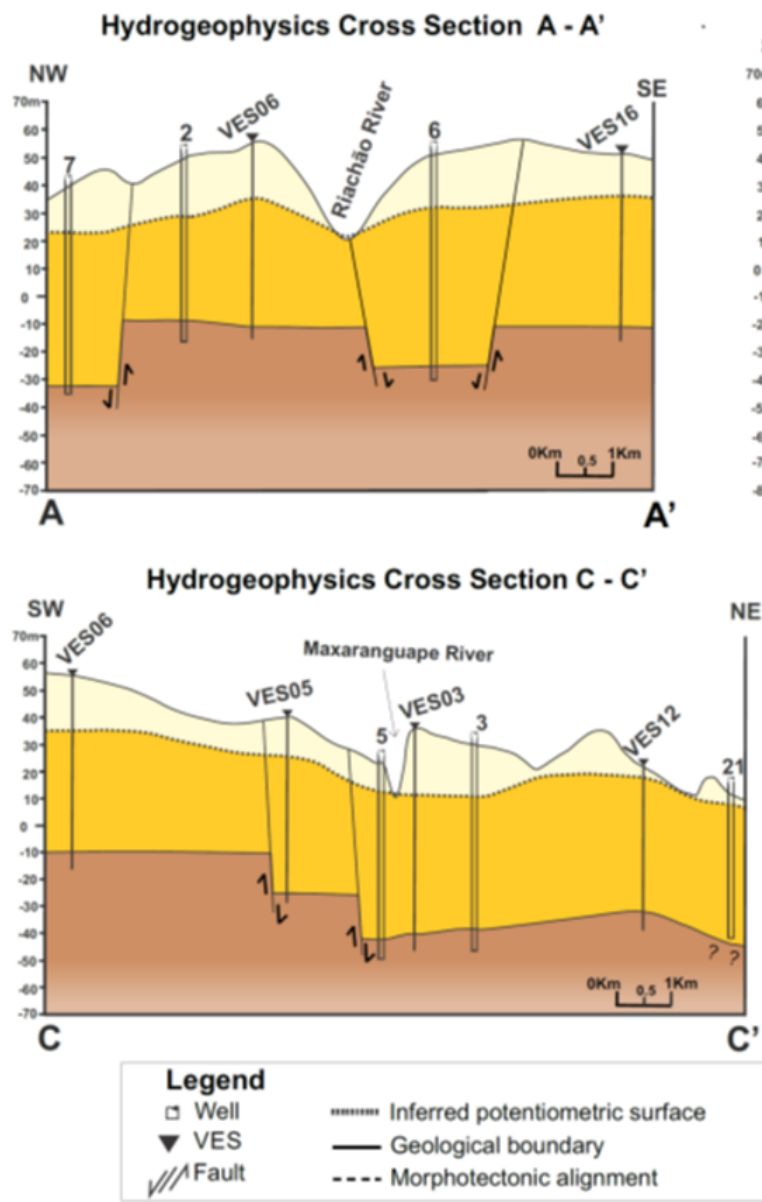

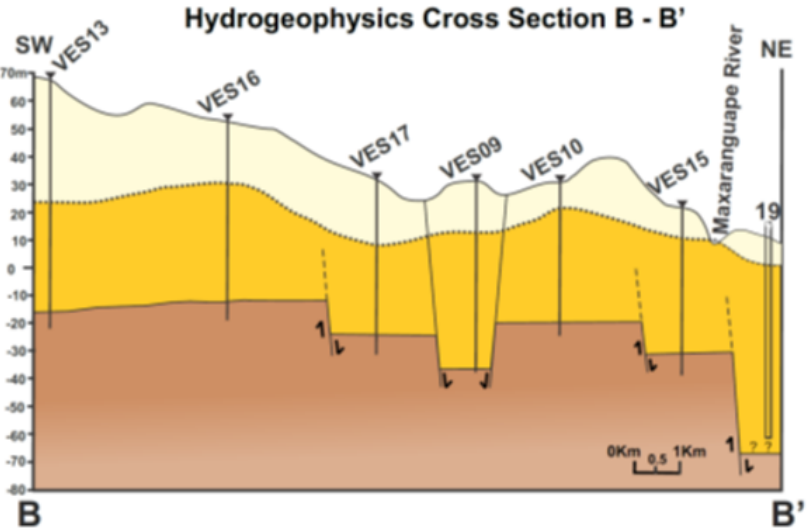

Hydrogeophysics Cross Section D - D'

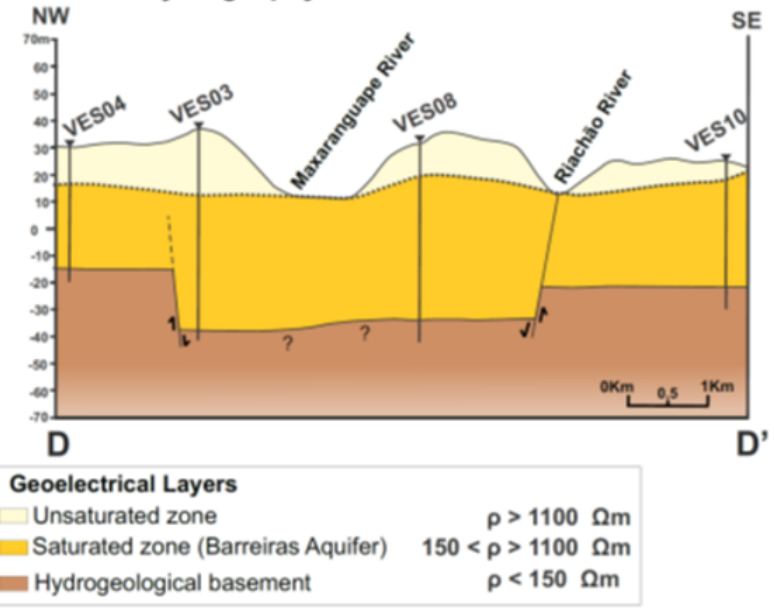

Figure 9. The hydrogeophysical cross-sections, A-A, B-B', C-C' and D-D', highlight depth variations of the top of the hydrogeological basement and thicknesses of the Barreiras Aquifer associated with faults; see localization in Fig. 1. 
most expressive morphotectonic alignments that were highlighted by processing (see Figs. 4 and 5) or those that characterized the slips (see Fig. 9) are present in Figure 10.

Figure 11 shows details of the relationship between aquifer thickness with local faults and the simplified conceptual structure of the subsurface associated with reservoir compartmentalization. Here, observation of the occurrence of greater and smaller thickness zones in the middle of the aquifer, which are conditioned to structural features of the hydrogeological basement, is possible.

Details of the structure of the area reveal 18 subareas based on discontinuities identified in Figure 10, defined as faults or morphotectonic alignments, in addition to the geographical boundaries of the basin (Fig. 12). This delimitation allowed an optimized evaluation of the reserves since it was possible to set the aquifer thickness values for each of the subareas. In general, the latter displayed quite distinct areas, with the largest in the central-western portion of the map (A10) (about $32.3 \mathrm{~km}^{2}$ ) and the smallest covering $3.5 \mathrm{~km}^{2}$ in the center of Figure 12 (A9) and limited by morphotectonic alignments.
In particular, subarea $\mathrm{A} 4$ provides information from nearby wells with ST values ranging from 34 to $51 \mathrm{~m}$. This variability arises from the proximity of the drainage wells and the topography effect (Fig. 12B), alternatively characterizing faults.

A summary of the data considered in the assessment of hydrogeological reserves of the Barreiras Aquifer, after the definition of the subareas $\left(A_{n}\right)$ and $S T$ values $\left(B_{n}\right)$, is presented in Table 2, wherein $A_{n}$ and $B_{n}$ are highlighted. The hydrogeological reserve was calculated as the saturation volume $\left(\mathrm{V}_{\text {sтотАL }}\right)$ using Equations 1 and 2 and an effective porosity of $7.6 \%$.

For comparison purposes, a ST of $45 \mathrm{~m}$ was considered representative of the entire area (see Tab. 1), yielding a saturation volume of $835 \times 10^{6} \mathrm{~m}^{3}$ compared with $872 \times 10^{6} \mathrm{~m}^{3}$ based on reservoir compartmentalization, i.e., a $4.4 \%$ difference. This percentage changes depending on the ST associated with localized information extrapolated for the entire study area.

However, it is noteworthy that the evaluation of reserves is a continuously updating process. Therefore, the execution of additional VES, as well as the inclusion of information from new wells, are essential to minimize uncertainties. In this context,

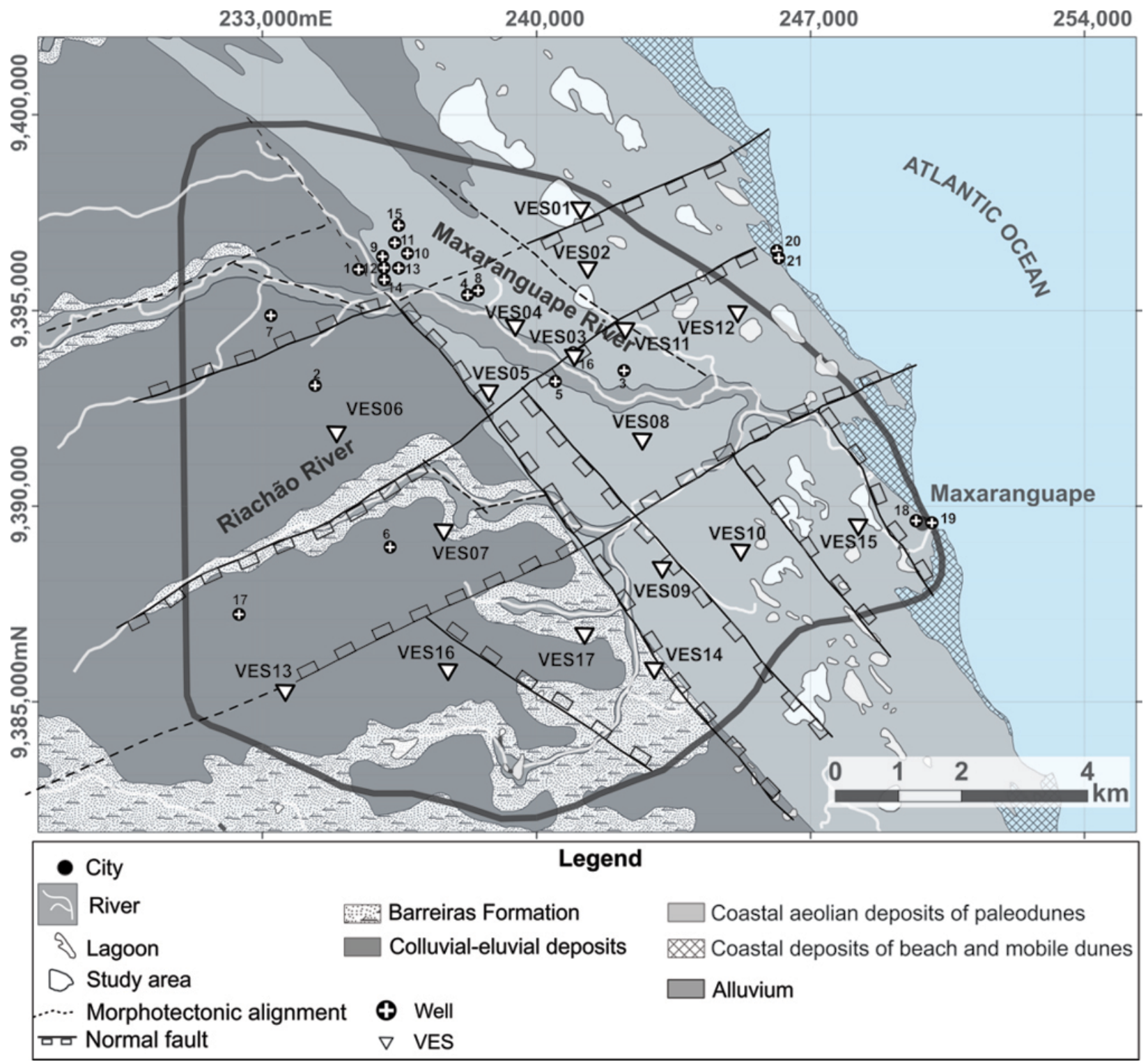

Figure 10. Structural and geological map of the area, modified from Angelim et al. (2006), showing morphotectonic alignments and faults. 
the ST values defined as representative of the same subareas should be improved as they were obtained from less available data or were based on inverse VES models only.

\section{CONCLUSIONS}

This research consisted of developing a methodology to improve the assessment of hydrogeological reserves of unconfined aquifers involving structural constraints. Primarily, the study sought to improve the structural characterization of the lower course of the Maxaranguape River area in Brazil. Initially, results of geomorphological analysis and topographical and hydrographical data were used, due to the absence of kinematic structural features at the local outcrop scale. Thus, anomalies in the drainage network and topographical landscape elements were identified, dominated by NW and NE trending morphotectonic alignments, given its tectonic and structural connotations. The association of some alignments as faults is attributed to the identification of the downthrow in hydrogeophysical cross-sections of

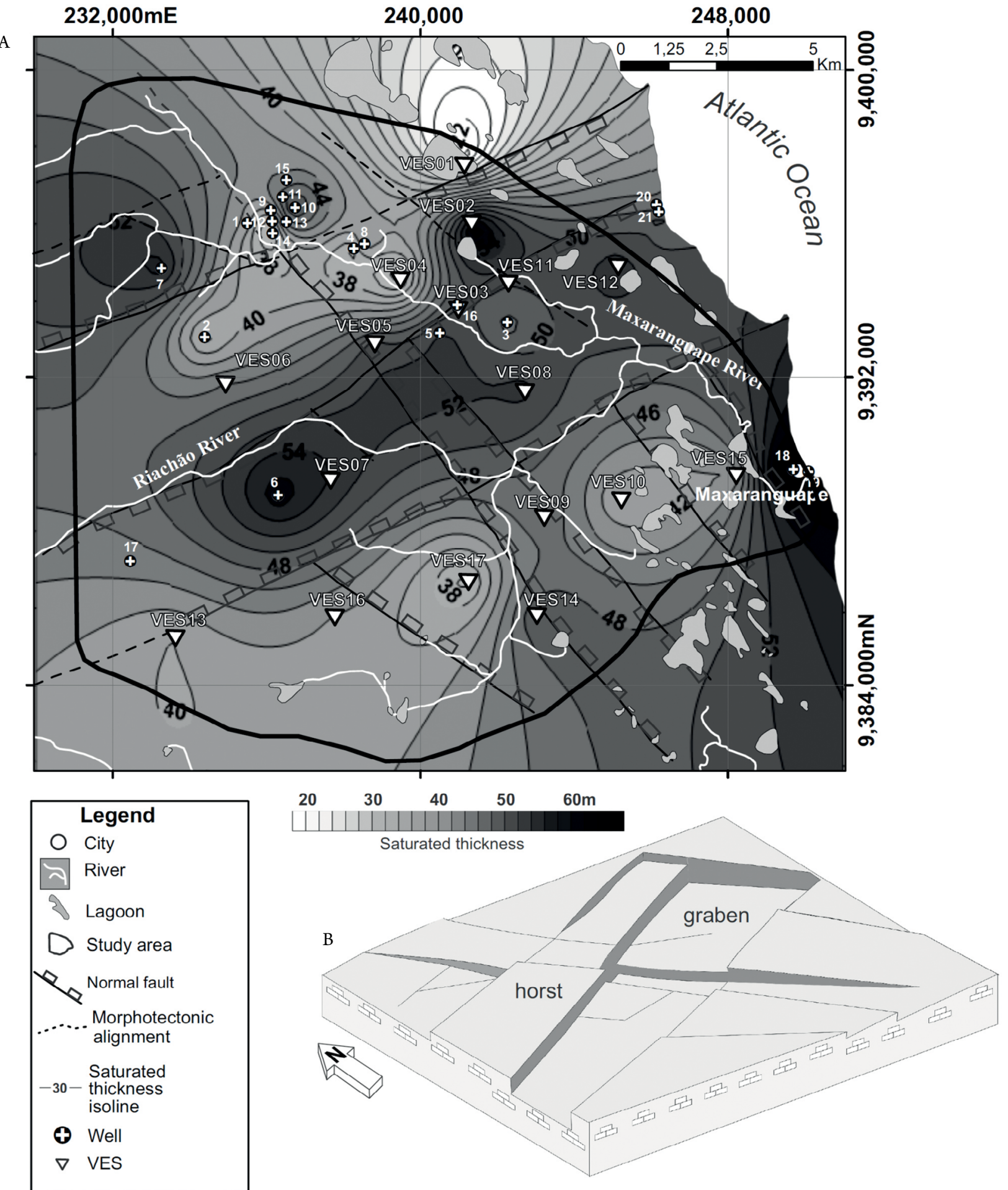

Figure 11. Synthesis of the relationship between aquifer thickness and regional structures (A). Simplified conceptual model of the Barreiras Aquifer compartmentalization (B). The main saturated thicknesses are associated with downfaulting of the hydrogeological basement, which is represented by the t88op of the Mesozoic carbonate sequence. 


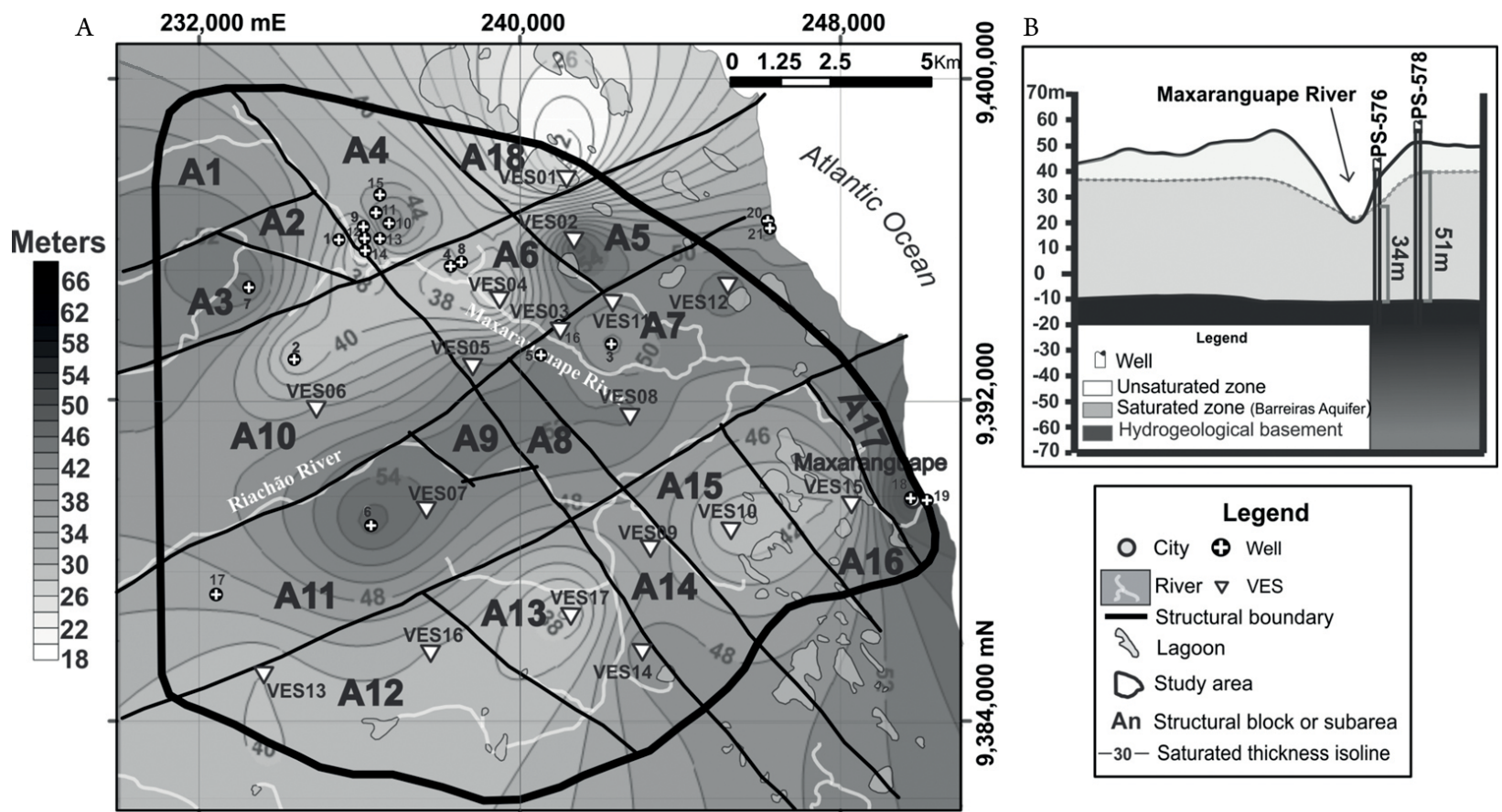

Figure 12. (A) Subdivision of the study site yielding 18 structural blocks; (B) topographical influence on the thickness values of areas adjacent to drainage.

Table 2. Parameters considered for the assessment of the saturation reserves for each subarea using a $7.6 \%$ effective porosity.

\begin{tabular}{lccc}
\hline Subareas & $\mathbf{A}_{\mathbf{n}}\left(\times \mathbf{1 0}^{\mathbf{6}} \mathbf{m}^{\mathbf{2}}\right)$ & $\mathbf{B}_{\mathbf{n}}(\mathbf{m})$ & $\mathbf{V}_{\mathbf{s} \mathbf{n}}\left(\mathbf{m}^{\mathbf{3}}\right) \times \mathbf{1 0}^{\mathbf{6}}$ \\
\hline A1 & 9.94 & 49 & 37.02 \\
A2 & 4.04 & 43 & 13.2 \\
A3 & 8.35 & 49 & 31.1 \\
A4 & 15.42 & 43 & 50.39 \\
A5 & 6.85 & 50 & 26.03 \\
A6 & 11.61 & 39 & 34.41 \\
A7 & 26.24 & 51 & 101.71 \\
A8 & 5.33 & 50 & 20.25 \\
A9 & 3.46 & 52 & 13.63 \\
A10 & 32.29 & 45 & 110.43 \\
A11 & 31.26 & 51 & 121.01 \\
A12 & 31.05 & 42 & 99.11 \\
A13 & 17.85 & 41 & 55.65 \\
A14 & 10.49 & 49 & 39.06 \\
A15 & 13.17 & 43 & 43.04 \\
A16 & 11.77 & 45 & 40.25 \\
A17 & 5.78 & 58 & 25.48 \\
A18 & 5.00 & 28 & 10.64 \\
TOTAL & $\mathbf{2 4 9 . 8 6}$ & & $\mathbf{8 7 2 . 4 2}$ \\
\hline
\end{tabular}

+ An: aquifer occurrence subarea; Bn: average saturated thickness; Vsn: saturation volume.

15 to $25 \mathrm{~m}$ in most cases, demonstrating compartmentalization of the aquifer.

The configuration of this compartmentalization enabled the characterization of the ST variation in subareas, limited by morphotectonic alignments or faults beyond the geographical boundaries of the basin. Therefore, 18 subareas were identified, providing corresponding saturation reserves, using a single effective porosity value. The total saturation reserves in the reported area were obtained from the sum of the reserves of the subareas, totaling $872 \times 10^{6} \mathrm{~m}^{3}$.

The proposed evaluation of reserves represents an alternative to the adoption of a single value and was assumed representative of the entire area of occurrence of the aquifer under prominent structural conditioning. This assessment may be improved for application in similar hydrogeological terrains. Such improvement may be performed by including the variability of the effective porosity (unconfined hydraulic aquifer) or storage coefficient (confined hydraulic aquifers) within the area considered (when such information is available) or by performing multiple aquifer tests.

Given the growing and permanent demand for the identification and subsequent preservation of areas with the most promising hydrogeological reserves, studies of this nature are an auxiliary tool for optimizing the management of hydrogeological resources.

\section{ACKNOWLEDGMENT}

The authors thank the Brazilian Research Council CNPq for support through grant no 473625/2013-0. We also thank the anonymous reviewers for suggestions and comments that greatly improved the original work.

\section{ARTICLE INFORMATION}

Manuscript ID: 20180127. Received on: 11/12/2018. Approved on: 02/06/2020.

L. N. wrote the first draft of the manuscript and prepared all figures; L. L. provided advisorship regarding the methodology and its applications, as well as improved the manuscript through corrections and suggestions; C. S. provided advisorship regarding regional geology and the morphotectonic analysis.

Competing interests: The authors declare no competing interests. 


\section{REFERENCES}

Angelim L.A.A., Medeiros V.C., Nesi J.R. 2006. Programa Geologia do Brasil - PGB. Projeto Geologia e Recursos Minerais do Estado do Rio Grande do Norte. Mapa geológico do Estado do Rio Grande do Norte. Escala. 1:500.000. Recife: CPRM/FAPERN. Available at: <http://geobank. sa.cprm.gov.br>. Accessed on: January 19, 2015.

Balsamo F., Storti F., Salvini F., Silva A.T., Lima C.C. 2010. Structural and petrophysical evolution of extensional fault zones in low-porosity, poorly lithified sandstones of the Barreiras Formation, NE Brazil. Journal of Structural Geology, 32(11):1806-1826. http://doi.org/10.1016/j. jsg.2009.10.010

Bezerra F.H.R. 1998. Neotectonics in northeast Brazil. PhD Thesis, University of London, London.

Bezerra F.H.R., Amaro V.E., Vita-Finzi C., Saadi A. 2001. PlioceneQuaternary fault control of sedimentation and coastal plain morphology in NE Brazil. Journal of South American Earth Sciences, 14(1):61-75. http:// doi.org/10.1016/S0895-9811(01)00009-8

Bezerra F.H.R. \& Vita-Finzi C. 2000. How active is a passive margin? Paleoseismicity in northeastern Brazil. Geology, 28(7):591-594. http://doi. org/10.1130/0091-7613(2000)28<591:HAIAPM>2.0.CO;2

Bezerra F.H.R., Rossetti D.F., Oliveira R.G., Medeiros W.E., Brito Neves B.B., Balsamo F., Nogueira F.C.C., Dantas E.L., Andrades Filho C., Góes A.M. 2014. Neotectonic reactivation of shear zones and implications for faulting style and geometry in the continental margin of NE Brazil. Tectonophysics, 614:78-90. http://doi.org/10.1016/j.tecto.2013.12.021

Bobachev A.A., Modin I.N., Shevnin V.A. 2000. IPI2Win v. 2.1, IPI RES2, IPI_RES3, User's Guide. Geoscan-M Ltd. Moscow, Russia.

Burazer M., Zitko V., Radakovic D., Pararezanovic M. 2010. Using geophysical methods to define the attitude and extension of water-bearing strata in Miocene sediments of Pannonian Basin. Journal of Applied Geophysics, 72(4):242-253. http://doi.org/10.1016/j.jappgeo.2010.10.002

Christakos G. 2000. Modern Spatiotemporal Geostatistics. New York, Oxford University Press.

Custodio E. \& Llamas M.R. 1983. Hidrología Subterrânea. 2a ed. Barcelona, Omega.

Diaz D., Maksymowicz A., Vargas G., Vera E., Contreras-Reyes E., Rebolledo S. 2014. Exploring the shallow structure of the San Ramón thrust fault in Santiago, Chile $\left(\sim 33.5^{\circ} \mathrm{S}\right)$, using active seismic and electric methods. Solid Earth, 5:837-849. http://doi.org/10.5194/se-5-837-2014

Feitosa F.A.C., Manoel Filho J., Feitosa E.C., Demetrio J.G.A. 2008. Hidrogeologia: Conceitos e Aplicações. 3. ed. Rio de Janeiro, CPRM / LABHID.

Jordan G., Meijninger B.M.L., Van Hinsbergen D.J.J., Meulenkamp J.E., Van Dijk P.M. 2005. Extraction of morphotectonic features from DEMs: Development and applications for study areas in Hungary and NW Greece. International Journal of Applied Earth Observation and Geoinformation, 7(3):163-182. http://doi.org/10.1016/j.jag.2005.03.003

Kirsch R. 2009. Groundwater geophysics: a tool for hydrogeology. Germany, Springer.

Landim P.M.B. 2003. Análise Estatística de Dados Geológicos. 2. ed. São Paulo, UNESP.

Lucena L.R.F. 2005. Implicação da compartimentação estrutural no Aquifero Barreiras na área da bacia do Rio Pirangi-RN. Tese de Doutorado, Universidade Federal do Paraná-UFPR.

Lucena L.R.F. 2018. O condicionamento por falhas geológicas de um aquífero freático. Brasil, Novas Edições Acadêmicas.

Lucena L.R.F., Oliveira Jr. J.G., Medeiros W.E., Queiroz M.A. 2013. The potential of the Barreiras Aquifer in the lower course of the Doce River, Rio Grande do Norte State, Northeast Brazil - Integration of hydrogeological and geophysical data. Brazilian Journal of Geophysics, 31(1):43-57. http:// dx.doi.org/10.22564/rbgf.v31i1.245

Lucena L.R.F., Rosa Filho E.F., Hindi E.C. 2006. O controle estrutural no Aquífero Barreiras - área da bacia do Rio Pirangi-RN. Águas Subterrâneas, 20(1):83-98. http://doi.org/10.14295/ras.v20i1.9715

Lucena L.R.F., Silva, L.R.D., Vieira M.M., Carvalho B.M., Xavier Jr., M.M. 2016. Estimating hydraulic parameters of Açu-Brazil aquifer using the computer analysis of micrographs. Journal of Hydrology, 535:61-70. http:// doi.org/10.1016/j.jhydrol.2016.01.025

Melo J.G., Morais S.D.O., Silva R.A., Vasconcelos M.B. 2013. Avaliação dos recursos hídricos na Bacia do Rio Maxaranguape-RN. Águas Subterrâneas, 27(1):53-64. http://doi.org/10.14295/ras.v27i1.26875

Miranda E.E. 2015. Brasil em Relevo. Campinas, Embrapa Monitoramento por Satélite. Available at: http://www.relevobr.cnpm.embrapa.br. Accessed on: May 5, 2015.

Nogueira F.C.C., Bezerra F.H.R., Castro D.L. 2006. Deformação rúptil em depósitos da Formação Barreiras na porção leste da Bacia Potiguar. Geologia USP Série Científica, 6(2):51-59. http://dx.doi.org/10.5327/ S1519-874X2006000300007

Orellana E. 1972. Prospecion geoeletrica en corriente continua. Madrid, Paraninfo.

Pelletier J.D. 2013. A robust, two-parameter method for the extraction of drainage networks from high-resolution digital elevation models (DEMs): Evaluation using synthetic and real-world DEMs. Water Resources Research, 49(1):75-89. http://dx.doi.org/10.1029/2012WR012452

Pilli A., Sapigni M., Zuppi G.M. 2012. Karstic and alluvial aquifers: conceptual model for the plain - Prealps system (northeastern Italy). Journal of Hydrology, 464-465:94-106. http://dx.doi.org/10.1016/j.jhydrol.2012.06.049

Reis A.F.C., Bezerra F.H.R., Ferreira J.M., Nascimento A.F., Lima C.C. 2013 Stress magnitude and orientation in the Potiguar Basin, Brazil: Implications on faulting style and reactivation. Journal of Geophysical Research: Solid Earth, 118(10):5550-5563. http://dx.doi.org/10.1002/2012JB009953

Righetto A.M., Dias D.F. 2016. Balanço hídrico do Sistema Aquífero Barreiras na bacia hidrográfica do Rio Pitimbu-RN. Águas Subterrâneas, 30(3):394-410. http://dx.doi.org/10.14295/ras.v30i3.28620

Rodrigues M.A.C., Lucena L.R.F., Souza I.V.F. 2011. Preliminary geometric model of the Barreiras Aquifer derived from hydrogeophysics data at the River Catu basin, NE Brazil. In: International Congress of the Brazilian Geophysical Society, 12, 2011. Annals... Rio de Janeiro.

Rossetti D.F., Bezerra F.H.R., Góes A.M., Valeriano M.M., Andrades Filho C.O., Mittani J.C.R., Tatumi S.H., Brito Neves B.B. 2011. Late Quaternary sedimentation in the Paraíba Basin, Northeastern Brazil: Landform, sea level and tectonics in Eastern South America passive margin. Palaeogeography, Palaeoclimatology, Palaeoecology, 300(1-4):191-204. http://dx.doi. org/10.1016/j.palaeo.2010.12.026

Silva L.R.D., Lucena L.R.F., Vieira M.M., Nascimento A.F. 2014. Estimativa de parâmetros hidráulicos do Aquífero Barreiras-RN a partir de análise computacional de imagens de lâminas delgadas. Águas Subterrâneas, 28(2):14-27. http://dx.doi.org/10.14295/ras.v28i2.27873

Soares A.P., Soares P.C., Bettú D.F., Holtz M. 2007. Variabilidade espacial no Sistema Aquífero Guarani: controles estruturais e estratigráficos. Águas Subterrâneas, 21(1):51-64. https://doi.org/10.14295/ras.v21i1.16167

Souza I.V.F., Lucena L.R.F., Bezerra F.H.R., Diniz Filho J.B. 2019. Use of hydrogeophysical data to determine the role of faults in the geometry of Barreiras Aquifer, Brazil. Brazilian Journal of Geology, 49(2). https://doi. org/10.1590/2317-4889201920170141

Surfer. 2010. Contouring and 3D Surface Mapping for Scientists and Engineers. Colorado, Golden Software, Inc. Available at: < http://www.goldensoftware. com>. Accessed on: February 02, 2016. 